\title{
Boende och stöd - \\ En nationell inventering av kommunernas \\ boendeinsatser för utsatta \\ grupper
}

\author{
MATS BLID
}

Artikeln redovisar en nationell inventering av boendeinsatser för människor som av olika orsaker saknar stabilitet

i sitt boende. Med boendeinsatser avses både personella

stödinsatser $i$ hemmet och erbjudanden om olika fysiska boendemiljöer. Insatserna studeras utifrån olika karaktäristika och utifrån de övergripande dimensionerna normalitet och omsorg.

\section{Introduktion}

Studien handlar om kommuners insatser för människor som av olika anledningar har svårigheter att upprätthålla stabilitet $\mathrm{i}$ sin boendesituation. Den redovisar en nationell inventering $i$ ett representativt urval av landets kommuner och undersöker hur insatserna kan beskrivas. Studien är den

Mats Blid, doktorand, institutionen för socialt arbete, Mittuniversitet, Östersund mest ingående i sitt slag och den första kartläggningen på två decennier.

Ett hem kan ses som en basal rättighet och en central komponent i människors vardag för möjligheter till livskvalitet, oberoende och delaktighet. Rätten till en bostad tas upp i svensk grundlag: „Det skall särskilt åligga det allmänna att trygga rätten till arbete, bostad och utbildning samt verka för social omsorg och trygghet och för en god levnadsmiljö“ (Regeringsformen 1 kap. 2§, 1976 i SOU 2001:95). Kom- 
munerna har det grundläggande ansvaret för bostadsförsörjning (Lag om kommunernas bostadsförsörjningsansvar, 2000:1383). De ska också bistå dem som av olika anledningar inte själva kan ordna eller behålla ett lämpligt boende, vilket regleras dels i LSS (Lagen om Stöd och Service till vissa funktionshindrade, 1993:387, 9 §) dels i socialtjänstlagen (SoL, 2001:453, 3 kap. 2 §). I och med genomförandet av psykiatrireformen 1995 betonades kommuners ansvar för utsatta gruppers boende ytterligare. Detta ansvar är dock inte rättsligt bindande, dvs. inte preciserat som en skyldighet att tillhandahålla boende till alla som saknar detta, utan skall snarare betraktas som en politisk målsättning (SOU 2001:95). Endast för två grupper, vissa äldre och funktionshindrade, finns uttrycklig skyldighet att bistå. När det gäller övriga säger lagstiftningen inget specifikt om hur socialtjänsten skall agera för att hjälpa människor att uppnå boendestabilitet.

\section{Vemärhemlös?}

Genom att utgå från vad som konstituerar ett "hem" presenterar Meert et al. (2004) en modell för att förstå vad hemlöshet innebär och hur begreppet kan operationaliseras. Avsaknad av ett adekvat hem kan förstås som frånvaron av ett privat utrymme där sociala och privata relationer kan upprätthållas och över vilket man har lagenlig rätt. Utifrån denna utgångspunkt kan individen vara mer eller mindre hemlös. De föreslår att hemlösa grovt kan indelas efter fyra olika boendesituationer: 1. "de taklösa" (roofless), t.ex. uteliggare; 2. "de bostads- lösa" (houseless), t.ex. de som övernattar i härbärgen eller ambulerar mellan bekanta; 3. "de med tillfälligt och osäkert boende" (insecure housing), t.ex. de med sociala kontrakt utan besittningsskydd; samt 4. „de i olämpligt boende" (inadequate accommodation), t.ex. de som bor på camping eller är trångbodda.

Studier av hemlösa över tid visar att deras mer eller mindre tillfälliga lösningar varierar kraftigt (SOU 2001:95, Gullberg \& Börjesson 2000, Gerdner \& Blid 2003, Hartwell 2003). En del av dessa "lösningar" äger rum med samhällets och frivilligorganisationers bistånd - t.ex. härbärgen, sociala övergångslägenheter - medan andra är privata sätt för individen att hantera problemet - t.ex. inneboende, ambulerande mellan tillfälliga bekanta, boende $\mathrm{i}$ källarlokaler eller kulvertar. Men medan „lösningarna» kan vara tillfälliga är ofta det grundläggande problemet - dvs. osäkerheten och instabiliteten i boendet - långvarigt (Gerdner \& Blid 2003). Hemlösheten kan därmed ses som ett kontinuum av olika mer eller mindre instabila lösningar i olika boendemiljöer. Detta medför olika avgränsningsproblem. Vilka boendelösningar skall ses som verkliga lösningar, dvs. insatser som fått det grundläggande problemet att upphöra, och vilka skall ses som temporär lindring? Kan insatserna värderas på ett meningsfullt sätt längs någon dimension som har betydelse i den hemlöses liv? Var skall gränsen dras för när man betraktas som hemlös?

Vid Socialstyrelsens tre genomförda inventeringar av individer vars boendesituation bedömts som mer eller mindre instabil har antalet varierat från c:a 8000 år 1993, 
c:a 8440 år 1999 till c:a 17800 år 2005. Utöver dessa tillkommer ett stort antal barn som mer eller mindre direkt påverkas av att en eller båda föräldrarna är utan trygg boendesituation (SOU 2005:88). Alla tre inventeringarna har baserats på olika definitioner av vilka som skall inkluderas. Den definition som användes 1999 var snävare än den som tillämpades 1993. Bl.a. infördes en tidsbegränsning på tre månader för de som planerades att bli utskrivna från en vårdinrättning men som inte hade någon ordnad bostad (SOU 2000:14).

Den definition som användes 2005 var däremot vidare. Både de som ska skrivas ut från institutioner och olika stödboenden inom tre månader och de som inte ska skrivas ut räknas som hemlösa om de inte har sin boendesituation ordnad. Även de som har ett tillfälligt andrahands- eller inneboendekontrakt räknas som hemlösa (Socialstyrelsen 2006). Därmed liknar den senaste definitionen i sak den som användes 1993, men genom preciseringarna kan säkrare grupperingar göras, vilket också kan ha påverkat den faktiska räkningen. Förklaringar till ökningen mellan 1999 års beräkning och 2005 års är således dels de preciseringar och utökningar som skett i den senaste definitionen, dels ett utvidgat antal uppgiftslämnare - framförallt frivillighetsorganisationer - samt dels också troligen en reell ökning vars mer precisa omfattning det är svårt att uppskatta (a.a. s. 83).

\section{Kommunernas insatser}

Kommuner använder olika strategier för att hantera hemlöshetsproblemet. Börjeson
(2005) beskriver dessa utifrån målsättningarna med insatserna: att förhindra uppkomst av hemlöshet, att erbjuda medicinskt och/eller socialt stöd till hemlösa, samt att hjälpa de hemlösa (tillbaks) till ett mer ordnat boende. Viktiga inslag är att på olika sätt ge stöd till människor för att klara sin vardag och förhindra vräkningar samt att medverka till att återföra redan hemlösa till ett reguljärt boende, ibland föregånget av någon form av behandling eller rehabilitering. Den vanligaste orsaken till vräkning är obetald hyra. Socialtjänsten arbetar vräkningsförebyggande genom rådgivning och ekonomiskt bistånd (SOU 2005:88).Centrala verktyg för att hjälpa redan bostadslösa klienter och de som bedöms ha svårt att hantera sitt boende är boendeinsatser, vilka kan indelas i två grupper.

Insatsen boendestöd är en personell resurs för att bistå individen att hantera problem förknippade med boendet, bl.a. ägnade att förebygga problem som skulle kunna leda till misär och vräkning. Den kan organiseras genom kommunens socialpsykiatriska verksamhet eller genom individ- och familjeomsorgen (IFO) och den förmedlas som regel i individens bostad av s.k. "boendestödjare» eller "boendeteam». Inom IFO förekommer också s.k. hemmahosare som kan ge likartat boendestöd men som också kan ha vidare syften.

Dessutom kan socialtjänsten ge insats $i$ form av boende, dvs. en fysisk miljö för boende med olika kvalitet och innehåll som ibland begränsas till boendet som sådant och emellanåt även rymmer andra slags tjänster. Det kan tillhandahållas i kommunala institutioner eller i verksamheter som drivs av andra huvudmän men finansieras

Mats Blid: Boende och stöd - En nationell inventering av kommunernas... 
helt eller delvis med kommunalt bistånd. Det kan handla om härbärge, hotellboende förmedlat genom socialtjänsten, jourlägenhet och lågtröskelboende, utslussningslägenhet, inackorderingshem, kategoriboende, träningslägenhet, socialt övergångskontrakt samt boendelösningar i samband med missbrukar- och psykvård.

Med begreppet boendeinsatser avses fortsättningsvis båda dessa slag av insatser. Det kan tilläggas att de också kan kombineras, t.ex. boendestöd som ges till någon som bor i en bostad med socialt kontrakt.

\section{Skilda perspektiv på boendeinsatser}

Internationell forskning om boendeinsatser har ofta varit i form av utvärderingsforskning av boendeprogram. Dessa program har i sin tur haft olika utgångspunkter. En typ av insatser har utgått från andra problem som den hemlöse kan ha, t.ex. missbruk och psykisk sjukdom, och som bidragit till hemlösheten. I denna modell kan olika temporära boenden utgöra en del av en vårdkedja, s.k. continuum of care programs (se t.ex. Bebout 1999, Cullhane et al. 2002). Tidigt i kedjan har boendet mer institutionskaraktär och senare är det mer hemlikt.

En annan modell, s.k. housing support, ser boende som en grundläggande rättighet som måste ordnas först och där eventuella övriga insatser är frivilliga tillval (se t.ex. Tsemberis \& Eisenberg 2000, Busch-Geertsema 2001). Även här betonas dock vikten av s.k. case management för att se till att insatser för övriga problem verkligen erbjuds. Det ses som förutsättning för att boendet skall kunna fungera stabilt. Båda dessa modeller innehåller således inslag av vård och omsorg, men de skiljer sig när det gäller synen på temporära boendelösningar (för en närmare översikt, se Blid \& Gerdner 2006).

En utgångspunkt för housing supportmodellen är att erbjudandet om eget kontrakt i normal boendemiljö skall ge positiva effekter på den f.d. hemlöse genom att interaktionen med socialt fungerande grannar bidrar till att denne hanterar sina övriga problem bättre. Det finns därmed en mycket positiv syn både på de hemlösa och på det omgivande samhället. En annan modell gör ännu starkare betoning på denna s.k. normalisering, då man utgår från att vård och omsorg därmed inte längre skall behövas. Boendet som sådant blir den insats som krävs, s.k. housing as housing (Ridgway \& Zipple 1990).

Det finns ett par ytterligare modeller, som $\mathrm{i}$ likhet med denna inte betonar vårdinsatser, utan ger boende som isolerad insats, men som skiljer sig när det gäller synen på interaktionen med det omgivande samhället. Utifrån dessa modeller saknar den hemlöse "förmågan att bo" $i$ ett normalt bostadsområde. Enligt en av dessa modeller, den s.k. trappstegsmodellen eller stair case model (Sahlin 2005), ses denna oförmåga som något som kan tränas. Den hemlöse får börja med trappsteg "långt ned" i hierarkin, i härbärge eller andra lågtröskelalternativ, för att successivt kvalificera sig till träningslägenhet och socialt kontrakt med sikte på egen lägenhet.

Det finns också ett mer passivt synsätt på de hemlösa, som antar att de endast kan bo i separata boendelösningar tillsammans med andra med samma problem, vid 
sidan om vanliga bostadsområden. Blid och Gerdner (2006) har studerat två kategorihus med denna inriktning. Studien visade att trots förbättrad boendesituation fanns inga andra positiva sidoeffekter i form av minskat missbruk eller varaktigt förbättrad boendestabilitet. Kategoriboendemodellen kan ses som uttryck för en »institutionaliserad resignation " (Järvinen 2001).

Både internationellt och nationellt har framhållits att forskning om sociala insatser mot hemlöshet och resultat av dessa är begränsad(Fitzpatrick et al. 2000, Socialstyrelsen 2000). Från ett europeiskt perspektiv framfördes tidigt $i$ en rapport till FEANTSA (Fédération Européenne d'Associations Nationales Travaillant avec les Sans-Abri/ European Federation of National Organisations working with the Homeless) att det finns stora brister i hur hemlöshetsproblemen hanteras. Det handlar om fragmenterade insatser som ges med bristfällig samverkan av olika hjälpande instanser. Det finns en övervikt av akuta insatser (härbärgen och soppkök), ofta från frivillighetsorganisationer, och ambitionen att hjälpa hemlösa tillbaks till normala bostäder har i regel låg prioritet (Daly 1992). Andra har pekat på en ökad omfattning av boendeformer med stöd $i$ kommunal regi men samtidigt en avsaknad av kunskap om dessa och en svårighet $\mathrm{i}$ att hitta rätt stödnivå på insatserna, vilket i sin tur kan leda till bl.a. hemlöshet (Regeringsbeslut 2003:09).

I Sverige har framför allt Sahlin undersökt socialtjänstens boendeinsatser (Sahlin 1993, 1996, 1999, 2005). Hennes forskning visar att socialtjänsten bidragit till att utveckla »den sekundära bostadsmarknaden« som en lokal strategi för att motverka att människor blir hemlösa eller för att skapa lösningar för dem som redan exkluderats på denna marknad, samt att systemet med boendetrappa är kontraproduktivt p.g.a. att ett fåtal individer tar sig igenom hela trappan utan istället faller ur och får börja om (Sahlin 2005). Trappan kan lika gärna gå nedåt som uppåt.

\section{Olika dimensioner för att beskriva boendeinsatser}

Det finns en stor flora av beteckningar för olika slags boendeinsatser. Gränserna är ofta otydliga och benämningarna kan ibland mer bero på målgrupper än på skillnader $\mathrm{i}$ själva insatsen (Sahlin 1996). Man kan inte heller vara säker på att samma beteckningar täcker samma slags insatser i olika kommuner. Vidare saknas kunskap om framträdande kvaliteter i olika typer av boendeinsatser och av det följer att det är befogat att inventera vilka insatser som faktiskt ges och beskriva dessa på ett strukturerat sätt utifrån givna kriterier.

Finns det några tydliga begrepp och dimensioner som kan användas för en beskrivning av dem? En grundläggande distinktion, enligt Bochel et al. (1999), kan göras mellan begreppen hem och institution. Utmärkande för ett hem är att det är ett privat utrymme som ägs eller hyrs av dem som bor där, ensamma eller tillsammans med närstående personer, och med autonomi, dvs. utan att stå under tillsyn från personal med överordnade befogenheter. På en institution gäller det motsatta. Man har svårt att ha ett privatliv p.g.a. att det är ett offentligt utrymme där man lever

Mats Blid: Boende och stöd - En nationell inventering av kommunernas... 
med främlingar och personal, och där någon annan har bestämmanderätt över boendeutrymmet (a.a.).

Ett centralt perspektiv, som varit vägledande inom såväl omsorgen av psykiskt funktionshindrade som i socialtjänsten i och med införandet av socialtjänstlagen (1982), är strävan mot en normalisering av boendet för att ge den enskilde möjligheten att leva autonomt i sin lägenhet och underlätta integrering i samhället (Edgar et al. 2000, Ericsson 2002, Sahlin 1999, SOU 2000:14, SOU 2001:95). En dimension som framhållits av enskilda forskare är trygghetsaspekten utifrån individens besittningsskydd (Gullberg \& Börjeson 2000). Den differentierar dock inte mellan socialtjänstens olika insatser som generellt förmedlas utan besittningsskydd.

Trygghet och normalisering fick konstituera en gemensam dimension när Gerdner och Blid (2003) rangordnade 18 olika boendelösningar - såväl offentligt erbjudna som spontant organiserade - för 210 hemlösa personer i fem olika kommuner. Med normalitet avsågs att boendet inte var negativt socialt utpekande och med trygghet avsågs den grad av stabilitet den enskilde har i sitt boende. I en senare studie av Blid och Gerdner (2006) diskuterades några dimensioner som skiljer olika slags boenden. En dimension handlar om inklusion $i$ respektive exklusion från normala bostadsområden. En annan dimension inbegriper graden av rehabiliterande insatser som är relaterat till boendet. En tredje dimension handlar om graden av varaktighet, dvs. i vilken utsträckning boendet är temporärt respektive permanent (Blid \& Gerdner 2006). Till dessa kan man utifrån Bochel et al. (1999) lägga graden av autonomi och graden av hemlikhet respektive institutionskaraktär $\mathrm{i}$ boendet. Mer specifika skillnader, som hör ihop med institutionskaraktären och dess uppdrag, kan handla om antal personal i boendet och utbildning för dessa samt i vilken utsträckning boendet är kringgärdat av regler som inte normalt är förknippade med boende.

Syftet med föreliggande artikel är att presentera en nationell översikt av boendeinsatser, baserad på en representativ undersökning i omkring hälften av landets kommuner, samt att utifrån denna redovisa vad som kännetecknar de olika insatserna, i vilken utsträckning de skiljer sig från varandra och om olika insatser kan ordnas längs några övergripande dimensioner.

Enkätundersökningen inbegriper boendeinsatser i form av bistånd riktade till vuxna som har problem med stabilitet i sitt boende. Många av dessa - men inte alla - har problem med missbruk, psykiska problem och/eller andra psykosociala problem. Ytterligare andra har främst ekonomiska problem. De insatser som berörs finns inom olika nämnders och verksamheters ansvarsområden, t.ex. socialnämnd, omsorgsnämnd eller äldre- och handikappsnämnd. Inom socialnämnden kan de höra till individ- och familjeomsorg (IFO), socialpsykiatrisk verksamhet och LSS-verksamheter. Boendeinsatser riktade primärt till minderåriga ingår inte i denna studie. Inte heller ingår insatser för de två grupper för vilka kommunerna har starkare lagstadgad skyldighet att tillhandahålla permanenta boenden, dvs. servicebostäder m.m. för äldre samt gruppboenden för funktionshindrade. Kvinnojourer ingår ej heller då 
de primärt är inriktade på skydd snarare än hemlöshet, även om kvinnornas situation kan medföra hemlöshet.

I denna artikel fokuseras således insatserna i sig och i en kommande artikel kommer fokus att ligga på de kommunala skillnader som finns och hur dessa kan förstås i en vidare kontext.

\section{Material och metod}

Redovisningen bygger på resultaten från en enkätundersökning. Studieobjekt är socialtjänstens boendeinsatser och undersökningen genomfördes från hösten 2004 till hösten 2005. Datainsamling skedde med hjälp av en webbaserad enkät i två delar. Del 1 riktades till kommunföreträdare - beroende på kommunstorlek var de oftast socialchefer, handläggare på staben eller områdes/enhetschefer - för ett representativt urval av Sveriges kommuner ( $\mathrm{n}=147)$. Del 2 riktades till företrädare för samtliga boendeinsatser som genom del 1 identifierats i dessa kommuner $(n=386)$.

\section{Urval och datainsamling}

Urvalet utgick från Svenska Kommunförbundets kommungruppsindelning av Sveriges kommuner i nio grupper (www.svekom.se 2003). Dessa grupper slogs samman till fem för att få större underlag i varje grupp för slumpmässiga urval. Därefter gjordes ett 50-procentigt urval inom varje grupp vilket resulterade i ett urval på 147 kommuner. Urvalet kommuner ser därmed ut enligt följande: en storstadskommun, 18 förorts- kommuner, 34 större och medelstora städer, 28 industrikommuner, 30 landsbygds- och glesbygdskommuner samt 36 övriga kommuner. Den storstad som ingår, Malmö, slumpades ej då slumpning är meningslöst i en grupp av tre, utan valdes utifrån tidigare forskningssamarbete. Enligt Socialstyrelsen (2000) är omfattningen av hemlösheten per invånare och hemlöshetens karaktär ungefär lika i de tre storstäderna. Då eventuell generalisering från urval till skattning för hela landet görs måste dock hänsyn tas till att Malmö är befolkningsmässigt mindre.

Samtliga kommuner som utvalts har, efter omfattande uppföljningsarbete, besvarat enkäten. För del 1 finns således inget bortfall. Från dessa kommuner har sammanlagt 386 boendestödsverksamheter inrapporterats. Även här finns svar från samtliga dessa men med visst internt bortfall. Ett omfattande arbete för att få komplett datauppsättning gjordes genom telefonintervjuer utifrån enkäten. Sammanlagt har 84 kommuner (58\%) följts upp på detta sätt framförallt genom intervjuer med representanter inom både IFO och socialpsykiatrin. Trots detta finns dock fortfarande ett internt bortfall avseende enstaka variabler spritt över 75 av 386 verksamheter (20 \%). Uppföljningsarbetet medförde att datainsamlingen drog ut på tiden. Det bör dock inte ha påverkat data negativt, eftersom intervjuerna visade att insatserna varit oförändrade under sista året.

\section{Enkätens utformning}

Innan den slutliga enkäten utformades och distribuerades via e-post hade ett antal

Mats Blid: Boende och stöd-En nationell inventering av kommunernas... 
provenkäter testats på kommuner av olika storlek vilket resulterade i smärre justeringar. Den fastställda versionen utformades med hjälp av datorprogrammet E-val (LUVIT e-Val 4.0) och distribuerades via Internet. ${ }^{1}$

Enkätens delar ser ut som följer:

- Del 1, som ställdes till kommunföreträdare, berör respektive kommun mer övergripande. Den tar upp förekomst av policy och organiserande inslag kring bostadsfrågor $\mathrm{i}$ respektive kommun samt frågor om antal personer som är hemlösa och antal som är föremål för boendestödsinsatser. Enkätdel 1 avslutas med plats för uppräkning av de boendeinsatser som finns i kommunen. Den inventeringen ligger till grund för vilka som omfattas av del 2.

- Del 2 riktar sig till företrädare för respektive verksamhet men kunde också fyllas i av central kommunal företrädare om denne bedömde sig ha tillräcklig kännedom om verksamheten. Formuläret fylldes i för var och en av de i kommunen befintliga verksamheterna, vilka räknats upp i del 1. Enkätdel 2 innehåller inledningsvis en fråga om verksamhetens organisationstillhörighet. Därefter följer frågeområden om samarbete/samverkan finns och hur detta ser ut, omfattning av personalinsats, deras

1 E-val är ett webbaserat enkät- och utvärderingsverktyg för att bygga upp nätbaserade enkäter. Det har utvecklats vid Lunds universitet och Center for Educational Development. tillgänglighet fördelat över dygnet, personalens kompetens (omfattning och typ av utbildning och handledning), målgrupper för verksamheten, typ av boendeinsats (kategorisk benämning), karakteristik av verksamheten utifrån ett antal dimensioner. Enkäten avslutas med en fråga om förekomst av ett antal eventuella restriktioner och regler i boendeinsatsen.

\section{Variabler}

Följande variabler som beskriver boendeinsatserna används i analyserna. Först redovisas fem dimensioner som alla mättes med femgradiga Likertskalor $(0-4)$ :

- Grad av hemlikhet: Mäter dimensionen från institution till hemlikt boende (Institution/Mindre institutionsliknande boende/Gruppboende med viss hemlik karaktär/Enskilt boende med specialfunktion/Normalt hem i enskild lägenhet eller hus).

- Grad av integration: Mäter dimensionen från fullständigt separat boende till att boendet är lokaliserat inom och integrerat med det normala boendebeståndet (Helt separat, inga andra grannar inom synhåll/Andra grannar i angränsande bostadsområde/Andra grannar i samma bostadsområde, men i separat fastighet/Delvis integrerat med andra grannar i samma fastighet/Helt integrerat, andra grannar i samma trappuppgång eller liknande).

- Grad av varaktighet: Mäter boendets planerade varaktighet från högst tem- 
porärt till permanent (Högst tillfälligt boende/Relativt instabilt boende/Temporärt boende/Relativt stabilt boende/ Permanent boende).

- Grad av autonomi i boendet: Från endast tillgång till sängplats i sovsal till full dispositionsrätt av lägenhet (Ingen alls t.ex. kollektivt boende med sängplats i sovsal eller delat rum/Eget rum utan nyckel/ Eget rum med nyckel/Egen lägenhet med tillsyn/Fullständig autonomi t.ex. egen lägenhet, helt självständigt).

- Grad av rehabilitering: Mäter i vad mån insatsen är kopplad till omsorg, vård eller rehabilitering, från ingen alls till rehabiliterande insatser med hög grad av struktur (Inget alls, endast boende/ Tillsyn från personal/Social omsorg/ Rehabiliterande insatser med låg grad av struktur/Fullt ut, rehabiliterande insatser med hög grad av struktur).

Tre variabler utgörs av graderingar av personalfaktorer (graderingar av kompetensnivåer har i princip gjorts utifrån utbildningens längd).

- Personals medicinska professionella kompetens $(0-6)$ : (högsta nivå av följande kategorier: Ingen medicinsk kompetens/Vårdbiträde/Undersköterska/ Mentalskötare/Sjuksköterska/Antingen psyk- eller somaläkare/Både psyk- och somaläkare).

- Personals psykosociala professionella kompetens $(0-5)$ : (Högsta nivå av följande kategorier: Ingen psykosocial kompetens/Behandlingsassistent/Arbetsterapeut/Kurator/Psykolog, ej leg./Leg. psykolog eller leg. psykoterapeut).
- Personals tillgänglighet $(0-6)$ : Gradering av i vilken omfattning personal finns tillgänglig $i$ insatsen (Ingen personal/Personal men ej närvarande/Närvarande endast akut/Kortare schemalagd tid/Dagtid/Dag- och kvällstid/Dag, kväll och natt).

En variabel handlar om regler:

- Nivå på restriktivitet (0 - 9): Räknar antalet förekommande regler utifrån följande lista över sådana regler som inte brukar förekomma i normalt boende: inlåsning, restriktioner i geografisk rörlighet, besiktning av kläder och tillhörigheter, kroppsbesiktning, urinprover, obligatoriska aktiviteter, förbud mot införsel av rusdrycker droger, inpassering före visst klockslag samt andra regler.

\section{Hantering av internt bortfall}

Imputering användes för att hantera det interna bortfallet. ${ }^{2}$ Skälet för att genomföra imputering är att variablerna skall kunna användas i skapandet av indexskalor. Indexen bygger på medelvärden av fyra respektive fem variabler. Där värden på en eller ett par variabler saknas kommer indexet baseras på kvarvarande variabler. Att imputera där spridningen är låg ger då ett säkrare estimat i index än om imputering inte hade gjorts eftersom alla variabler ges samma vikt. Imputeringen gjordes gruppvis för olika boendeinsatser där upp-

2 Imputering innebär att skattade värden ersätter saknade värden. 
gift om hemlikhet, integration, autonomi och varaktighet saknades. Förutsättningen var dock att standardavvikelsen för uppgivna värden för samma grupp av insatser var lägre än 1 vilket innebär mindre än 25 procent av skalans längd. Under denna förutsättning fick medelvärdet på skalan för respektive grupp ersätta det saknade värdet. Boendestöd hanterades i detta sammanhang som två skilda grupper, dels de som uttryckligen organiserades inom kommunens socialpsykiatriska verksamhet, dels de som organiserades inom övrig IFO-verksamhet. På detta sätt kunde ytterligare 64 insatser få kompletta data. Fullständiga datauppsättningar finns därmed för 376 insatser (97,7 \%). Insatskategorier där imputering skedde var (med antal inom parentes): boendestöd (18), sociala övergångskontrakt (21), träningslägenheter (4), kategoriboenden (3), utsluss/halvvägshus (4). För övriga insatskategorier var spridningen på medelvärdet för stort för att imputering skulle kunna motiveras. Kvar finns därmed internbortfall för följande insatser: jour- och lågtröskelboende (7) och boende i missbrukar- och psykvård (2). Analyserna har gjorts både med och utan imputering.

\section{Statistiskanalys}

Utöver rent beskrivande analyser användes diskriminantanalys och faktoranalys (se Tabachnick \& Fidell 1996 för en utförligare diskussion).

Diskriminantanalys genomfördes för att undersöka vad som kännetecknar respektive insatsgrupp och om de på ett menings- fullt sätt skiljer sig åt utifrån olika beskrivande egenskaper (de ovan beskrivna nio variablerna). Denna analys gjordes på data utan imputering för att utgå från ickemanipulerat material $(n=321)$.

Faktoranalys gjordes för att undersöka om de olika beskrivande variablerna kan användas för att skapa meningsfulla och mer sammanfattande indexskalor enligt vilka olika slags konkreta boendeinsatser kan graderas. Den faktoranalytiska metod som användes var principalkomponentanalys med varimax rotation. Samma variabler användes som tidigare i diskriminantanalysen men med imputering $(\mathrm{n}=376)$.

\section{Typ och omfattning av boendeinsatser}

Totalt har de 386 verksamheter som inrapporterats grupperats av respondenter i tolv olika kategorier. I tabellen nedan redovisas dels antal insatser inom respektive kategori, dels andel av kommuner som tillhandahåller respektive insats. Insatser omfattar alla typer av boendeinsatser från akutinsatserna härbärgen, hotell och camping samt jour- och lågtröskelboende till insatser i mer permanenta boenden såsom sociala kontrakt och boendestöd. Vidare redovisas frekvens och andel personinsatser inom respektive insatsgrupp som tillhandahålls av kommunerna. Med personinsatser avses t.ex. antal sängplatser i härbärgen, antal lägenheter med övergångskontrakt eller antal personer som omfattas av boendestödjande verksamhet. Begreppet vårdboende $\mathrm{i}$ Tabell 1 avser boende $\mathrm{i}$ samband med psyk-och missbrukarvård.

Boendestöd med socialpsykiatrisk 
Tabell I.

Antal insatser ( $n=386)$, andel av kommuner $(n=147)$ som tillhandahailler respektive insats samt antal och andel personinsatser $(n=11$ 187), fördelat på 12 insatstyper

\begin{tabular}{lcccc}
\hline Typ av boendeinsats & $\begin{array}{c}\text { Antal } \\
\text { insatser }\end{array}$ & $\begin{array}{c}\text { Andel kommuner (\%) } \\
\text { som tillhandahåller } \\
\text { resp. insats }\end{array}$ & $\begin{array}{c}\text { Antal } \\
\text { person- } \\
\text { insatser }\end{array}$ & $\begin{array}{c}\text { Andel (\%) } \\
\text { person- } \\
\text { insatser }\end{array}$ \\
\hline Härbärge & 22 & 12 & 271 & 2,4 \\
\hline Hotell- och camping & 5 & 3 & 42 & 0,4 \\
\hline Jour/lågtröskelboenden & 34 & 20 & 220 & 2,0 \\
\hline Vårdboende & 33 & 18 & $44 \mid(a)$ & 4,0 \\
\hline Halwägshus & 1 & 1 & 10 & 0,1 \\
\hline Utslussningsboende & 7 & 5 & 28 & 0,3 \\
\hline Träningslägenhet & 25 & 15 & 431 & 4,0 \\
\hline Inackorderingshem & 1 & 1 & 10 & 0,1 \\
\hline Kategoriboende & 28 & 13 & 303 & 3,0 \\
\hline Sociala kontrakt & 93 & 58 & $3.880(\mathrm{~b})$ & 35,0 \\
\hline Boendestöd inom IFO & 24 & 19 & 455 & 4,0 \\
\hline Boendestöd inom social- & 13 & 81 & $5.096(\mathrm{c})$ & 46,0 \\
\hline Psykiatrin & & &
\end{tabular}

(a) Uppgifter om antal personinsatser baseras på 32 verksamheter.

(b) Uppgifter om antal personinsatser baseras på90 verksamheter.

(c) Uppgifter om antal personinsatser baseras på 112 verksamheter.

inriktning är den vanligaste insatsen följd av sociala övergångskontrakt. Det gäller oavsett om man ser till antal insatser, andelen kommuner som tillhandahåller insatsen, till antalet personinsatser som tillhandahålls. Dominansen är ännu större då man ser till deras andel av personinsatserna, totalt. Sex andra insatskategorier är därefter relativt vanligt förekommande. Vilka av dessa som är vanligast beror av ifall man jämför antal insatser, andel kommuner som tillhandahåller insatsen eller antal personinsatser som tillhandahålls. De sex är (efter antal personinsatser): boendestöd inom IFO, vårdboende, träningslägenheter, kategoriboende, härbärge samt jour- och lågtröskelboende.
Den senare insatstypen finns t.ex. i fler kommuner än de övriga men har jämförelsevis färre personinsatser. Övriga insatser - hotell- och camping, utslussningsboende, halvvägshus och inackorderingshem -är jämförelsevis ovanliga.

\section{Beskrivning av insatser}

Tabell 2 redovisar fördelningen av värden för respektive beskrivande variabler utifrån centraltendenser (median) och spridningsegenskaper (kvartilavvikelser). Parametrarna följer av att data är insamlade på ordinalskalenivå. 
Inte oväntat finns de högsta värdena för grad av hemlikt boende och integration inom insatserna sociala övergångskontrakt och de båda typerna av boendestöd. En allmän tendens är att de insatser som har höga värden på hemlikhet, integration, autonomi och varaktighet också har lägsta värdena på nivå på restriktivitet. Härbärgen, hotell- och camping samt jour- och lågtröskelboenden har alla låga värden på varaktighet vilket betyder att de kan betraktas som akutinsatser. Genomgående anges en låg nivå på grad av rehabilitering i boendeinsatserna. Den vanligaste nivån - värdet 1 - avser endast tillsyn av personal. Värdet 3 som endast uppnås i vårdboende och boendestöd inom IFO innebär nivån rehabiliterande insatser med låg grad av struktur. Ytterligare ett mönster är att de variabler som är förknippade med institutionsboenden och framförallt psykosocial kompetens varierar mer oberoende av typ av boendeinsats.

Vidare visar tabellen en avsaknad av medicinsk kompetens i så gott som alla insatser utom i boendestöd med socialpsykiatrisk verksamhet. En betydande skillnad mellan boendestöd med respektive utan socialpsykiatrisk verksamhet kan noteras för personalkompetens, där den senare har ett högt medianvärde för psykosocial kompetens och lågt på medicinsk kompetens medan det omvända förhållandet gäller för den förra.

Värdena för halvvägshus och inackorderingshem är baserade på en observation vardera. I de kommande analyserna ingår inte dessa två kategorier. Halvvägshus har förts till utslussningsboende och inackorderingshem till härbärge, beroende på att de hade störst likheter med dessa respektive gruppers variabelvärden.

\section{Utmärkande drag för respektive boendeinsats}

Vilka egenskaper är centrala för att beskriva en viss grupp av boendeinsatser? Kan boendeinsatserna grupperas/kategoriseras på ett tydligare sätt? Diskriminantanalys genomfördes för att beskriva och förklara skillnader mellan de olika boendeinsatserna. Analysen genomfördes på 321 verksamheter, dvs. alla med fullständiga data (utan imputering). I Tabell 3 visas hur diskriminantanalysen klarar att diskriminera, utifrån de nio variablerna, mellan de olika boendeinsatsgrupperna.

Tabell 3 visar utfallet av klassifikationen genom att ställa den faktiska grupptillhörigheten i relation till den predicerade. Raderna visar de empiriska kategorierna med totalt antal observationer längst till vänster och kolumnerna visar diskriminantanalysens klassificering utifrån variablerna. De nio ingående variablerna i diskriminantanalysen kunde totalt klassificera 65 procent av insatserna korrekt. Den låga andelen korrekt klassificerade för vissa insatsgrupper uppstår då de beskrivande variablerna inte tydligt skiljer mellan olika grupper av boendeinsatser. Andel korrekt klassificerade i respektive insatsgrupp framgår av de feta siffrorna på diagonalen i tabellen. De tydligaste beskrivna insatserna i analysen är således härbärge ( $87 \%$ ), utslussningsboende (80\%), boendestöd med socialpsykiatrisk verksamhet (73\%), sociala övergångskontrakt (73\%), hotell/camping (60\%) och jour- 


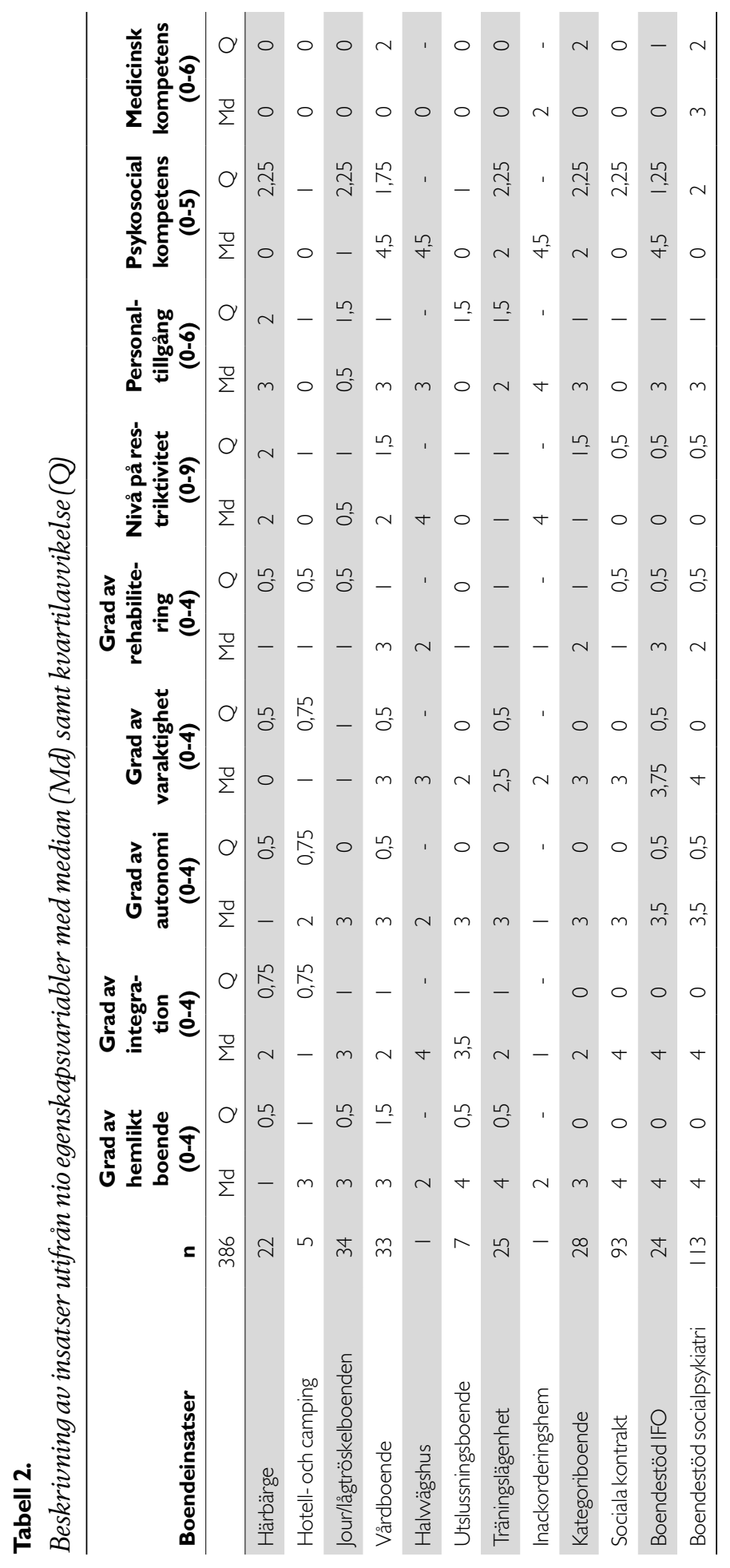

Mats Blid: Boende och stöd - En nationell inventering av kommunernas... 


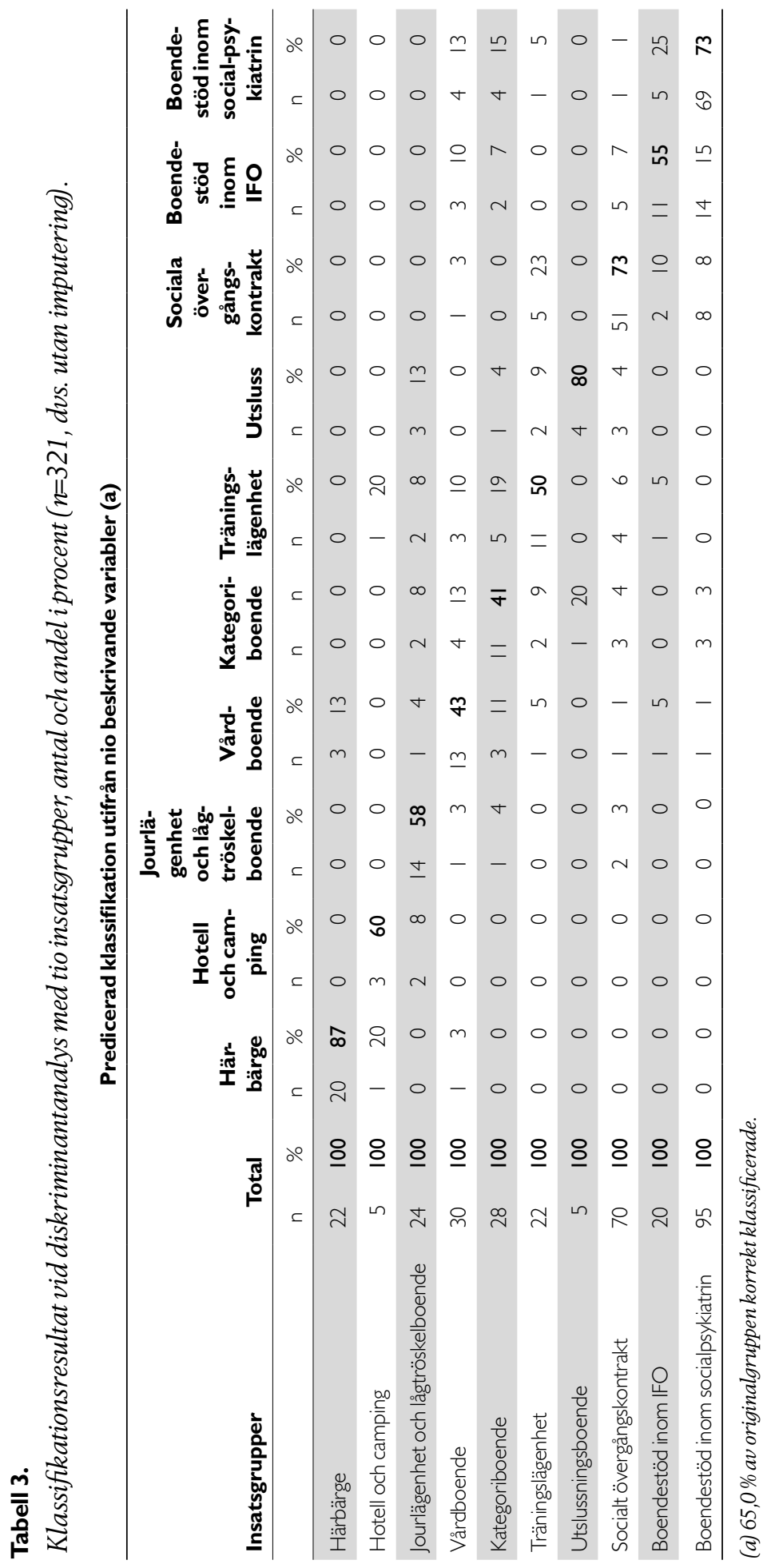

Socialvetenskaplig tidskrift nr 4 • 2006 
och lågtröskelboende (58 \%). För övriga fyra insatser ligger andelen mellan 41 - 55 procent. Ingen insatskategori har emellertid högre andel klassificerade i fel grupp. Några insatser har dock utspridda klassifikationer, t.ex. vårdboende och sociala övergångskontrakt som båda har felklassificerade insatser i sju andra grupper.

Den utbredda missklassifikationen av vårdboende till framförallt kategoriboende och socialpsykiatriskt boendestöd beror på stora variationer i kompetensnivå, regler och tillgång till omsorg inom vårdinstitutionerna. Teoretiskt borde variablerna grad av rehabilitering och psykosocial kompetens särskilja mellan vårdboende och kategoriboende men spridningen främst i den senare variabeln är stor för båda dessa insatsgrupper vilket leder till svårigheter att skilja dem åt.

Vilka variabler är det som främst skiljer insatserna åt? För att förklara detta måste vi titta närmare på diskriminantfunktionerna. För varje insats beräknas diskriminantpoängen utifrån variabelvärdena som viktas och summeras. I diskriminantanalysens strukturmatris redovisas respektive variabels korrelationsvärde i funktionerna som är ett mått på förmåga att diskriminera inom funktionerna. Diskriminantanalysen beräknar åtta diskriminantfunktioner eftersom nio oberoende variabler finns tillgängliga. Av dessa var fem signifikanta, men redan de två första funktionerna förklarar 84,4 procent av variansen. Därav följer att de två första funktionerna är de mest relevanta. De två diskriminantfunktionerna kan benämnas utifrån de mest utmärkande variablerna. Diskriminantfunktion 1 utmärks främst av varaktighet och auto- nomi och kan av det betecknas som en normalitetsfunktion. Härbärge och boendestöd är ytterligheter längs denna funktion. Diskriminantfunktion 2 utmärks främst av grad av rehabilitering, personaltillgång och medicinsk kompetens. Denna funktion kan då benämnas omsorgsfunktion. Den har ytterligheterna vårdboende respektive sociala övergångskontrakt.

\section{Övergripande dimensioner}

Frågan är då om det går att reducera våra variabelskalor på ett meningsfullt sätt för att undersöka om det finns överordnade homogena dimensioner. För att undersöka detta genomfördes faktoranalys på de nio beskrivande variablerna. En principalkomponent-analys med varimax rotation genomfördes. Totalt erhölls två faktorer med egenvärde större än 1. Faktorerna förklarar tillsammans 59,1 procent av variansen och överensstämmer väl med de två mest betydelsefulla funktionerna i diskriminantanalysen. Analysen visas i Tabell 4.

Utifrån dessa kunde två homogena index skapas. Fem faktorer - hemlikhet, integration, autonomi, varaktighet samt (med omvänd skattning) nivå på restriktivitet, laddar högt på faktor 1. Dessa har använts för att skapa ett normalitetsindex. Övriga fyra variabler - rehabilitering, personaltillgång, psykosocial kompetens samt medicinsk kompetens - laddar på faktor 2 och används för att skapa ett omsorgsindex. Varje kriterium har dividerats med sitt maximala möjliga värde (för att ha samma vikt i index). Index har bildats som genomsnitt av dessa vikter och kan därmed

Mats Blid: Boende och stöd - En nationell inventering av kommunernas... 
Tabell 4.

Principalkomponentanalys med varimax rotation för faktorer som beskriver olika insatser. Endast laddningar över $\pm 0,40$ visas. ( $n=376$ efter imputering).

\begin{tabular}{lcc}
\hline Andel förklarad varians & $\begin{array}{c}\text { Faktor I } \\
\text { Normalitet }\end{array}$ & $\begin{array}{c}\text { Faktor 2 } \\
\text { Omsorg } \\
\mathbf{2 2 , 0}\end{array}$ \\
\hline Grad av hemlikt boende & $\mathbf{3 2 , 3}$ & \\
Grad av integration & 0,83 & \\
Grad av autonomi & 0,77 & \\
Grad av varaktighet & 0,85 & $-0,41$ \\
Grad av restriktivitet (omvänd skattning) & 0,79 & 0,64 \\
Grad av rehabilitering & 0,63 & 0,82 \\
Personaltillgång & & 0,54 \\
\hline Psykosocial kompetens & & 0,72 \\
\hline Medicinsk kompetens & & \\
\hline
\end{tabular}

variera mellan 0 som motsvarar teoretiskt minimum och 1 som motsvarar teoretiskt maximum på respektive skala.

Skalornas interna konsistens har prövats med Cronbach's Alpha. För normalitetsindex var detta mycket tillfredsställande (alpha $=0,84$ ) och för omsorgsindex var det acceptabelt (alpha $=0,62$ ), dvs. fullt tillräckligt för medelvärdesskattningar på gruppnivå (Streiner \& Normann 1989). Indexskalorna är mycket modest korrelerade med varandra $(R=-0,13)$. Sammanfattningsvis är alltså dessa indexskalor separata, homogena och konsistenta.

\section{Sammanfattande beskrivning av respektive boendeinsats}

Medelvärden (M) och standardavvikelser
(Sd) för de olika boendeinsatserna (samtliga ursprungliga kategorierna) på de bägge indexskalorna visas i Tabell 5.

Skillnader i medelvärden på båda indexskalorna mellan de olika insatsgrupperna prövades med variansanalys. De två grupperna med vardera en insats kunde ej ingå $\mathrm{i}$ analysen. För bägge skalorna är skillnaderna starkt signifikanta (one-way ANOVA: $\mathrm{p}<$ 0,001). Post Hoc-testet Least Square Deviance klargör mellan vilka insatser skillnaderna finns.

I korthet visar detta att härbärge samt hotell och camping är de i tur och ordning minst normala insatserna medan de båda typerna av boendestöd är de mest normala följda av sociala övergångskontrakt. Omsorgsindexskalan visar att vårdboende är den mest omsorgsinriktade insatsen, följd av de båda boendestödsinsatserna och 
Tabell 5.

Insatsgruppernas fördelning längs normalitets- och omsorgsindex.

\begin{tabular}{|c|c|c|c|}
\hline Boendeinsatser & $\mathbf{n}$ & $\begin{array}{c}\text { Normalitetsindex } \\
\text { M(Sd) }\end{array}$ & $\begin{array}{c}\text { Omsorgsindex } \\
\text { M(Sd) }\end{array}$ \\
\hline Härbärge & 22 & $0,35(0,139)$ & $0,27(0,193)$ \\
\hline Hotell och camping & 5 & $0,48(0,172)$ & $0,12(0,145)$ \\
\hline Jourlägenhet och lågtröskelboende & 34 & $0,74(0,148)$ & $0,26(0,235)$ \\
\hline Vårdboende & 33 & $0,65(0,199)$ & $0,53(0,246)$ \\
\hline Halwägshus & 1 & $0,66(-)$ & $0,48(-)$ \\
\hline Utslussningsboende & 7 & $0,76(0,075)$ & $0,14(0,185)$ \\
\hline Inackorderingshem & 1 & $0,31(-)$ & $0,54(-)$ \\
\hline Kategoriboende & 28 & $0,7 \mid(0,103)$ & $0,43(0,219)$ \\
\hline Träningslägenhet & 25 & $0,74(0,110)$ & $0,29(0,209)$ \\
\hline Sociala övergångskontrakt & 93 & $0,87(0,079)$ & $0,18(0,188)$ \\
\hline Boendestöd inom IFO & 24 & $0,91(0,101)$ & $0,43(0,210)$ \\
\hline Boendestöd inom socialpsykiatrin & 112 & $0,93(0,081)$ & $0,4 I(0,25 I)$ \\
\hline Total & 386 & $0,80(0,189)$ & $0,33(0,248)$ \\
\hline
\end{tabular}

kategoriboende, medan de minst omsorgsinriktade är sociala övergångskontrakt, utslussningsboende, härbärgen, hotell och camping samt jourlägenheter och lågtröskelboende.

\section{Sammanfattning och diskussion}

De olika bondeinsatserna (utom de som endast förekom med enstaka fall) kan nu sammanfattas på följande sätt:

Härbärge är en boendeinsats som präglas av låg grad av normalitet och omsorg. Mer specifikt, det är en instabil och institutionsliknande insats som innehåller en hög grad av regler att följa och små möjligheter till privatutrymme. Personal med psykosocial kompetens är tillgänglig men de bedri- ver främst tillsynsarbete. Benämningen av verksamheten som "härbärge» är i hög utsträckning ett vedertaget begrepp som oftast betecknar samma sak i olika kommuner. Den förekommer i tolv procent av de undersökta kommunerna.

Hotell och camping, som finns i tre procent av kommunerna, är en boendeinsats som saknar både normalitet och omsorg. Insatsen framstår i huvudsak som exkluderande. Den är instabil och lågt integrerad med det normala bostadsbeståndet. Graden av rehabiliterande inslag är litet eller obefintligt och därför är heller ingen personal tillgänglig och inga speciella regler förekommer. Samtidigt medger detta en viss möjlighet till självständighet i boendet.

Jourlägenhet och lågtröskelboende, som finns i 20 procent av kommunerna, har ungefär samma låga omsorgsnivå som här-

Mats Blid: Boende och stöd - En nationell inventering av kommunernas.. 
bärgen, men är betydligt mer normalt i sin karaktär. Det är en utpräglad akutlösning, ofta integrerad med andra grannar i samma fastighet och i form av lägenhet med någon form av specialfunktion, men med obefintlig tillsyn från personal. Pga. att boendeformen är lägenhet sammanblandas den lätt med liknande lägenhetsinsatser såsom träningslägenhet och sociala övergångskontrakt vilka dock inte har samma karaktär av akutlösning.

De tre ovanstående boendeinsatskategorierna - härbärge, hotell och camping samt jour- och lågtröskelboende - har relativ entydiga benämningar för respektive kategori och de kan alla beskrivas som akutinsatser. Det är kortsiktiga boendelösningar och de är insatser som framförallt riktar sig till de som Meert et al. (2004) benämner de taklösa och bostadslösa och de förekommer sammantaget i 29 procent av kommunerna i urvalet.

Vårdboende, dvs. boende $\mathrm{i}$ samband med missbrukar- och psykvård finns i 18 procent av de undersökta kommunerna, och utmärks främst av hög grad av omsorg jämfört med övriga insatser, och relativt lågt värde på normalitet. Oftast är den inrymd $i$ en separat fastighet med grannar i samma bostadsområde. Har personal med hög tillgänglighet och hög psykosocial kompetens, men ej medicinsk, som utövar social omsorg och rehabiliterande åtgärder. Insatsen är förknippad med ett litet antal regler. Begreppet är inte entydigt beroende på att det finns stora variationer mellan olika vårdboenden framförallt vad gäller de institutionslika egenskaperna.

Kategoriboende, som finns i 13 procent av kommunerna, har medelhöga värden både på normalitetsindex och på omsorgsindex. Det är ett stabilt boende. Innehavarna bor oftast tillsammans i en separat fastighet men i var sina lägenheter med tillsyn och omsorg av personal. Personalen som finns tillgänglig dygnet runt har i varierande grad jämförelsevis hög medicinsk och psykosocial kompetens. Boendeinsatsen innehåller ett litet antal regler. Det som medverkar till högt normalitetsvärde är autonomin, stabiliteten och hemlikheten i boendet, samtidigt är insatsen separerad från normalt boendebestånd. Det är också en insats som blandas ihop med andra pga. att den har drag gemensamt med vårdboende, träningslägenhet och de två slagen av boendestöd.

Träningslägenhet finns i 15 procent av kommunerna och beskriver en insats som ligger relativt högt på normalitetsindex och som har en måttlig omsorgsnivå. Den är betydligt mindre institutionslik till sin karaktär än flertalet andra insatser, med få restriktioner. Den är oftast lokaliserad i separat fastighet men med andra grannar i samma bostadsområde och en relativt stabil insats. Endast personal med psykosocial kompetens förekommer. Den sammanblandas med sociala övergångskontrakt men skillnaden ligger $i$ att träningslägenhet är mindre integrerade i normalt boendebestånd, har mer regler och mer personal.

Utslussningsboende är en temporär boendelösning som förekommer i liten grad. Fem procent av kommunerna säger sig ha denna typ av insats. Den har relativt högt värde på normalitet men lågt värde på omsorgsindex. Även om insatsen är tänkt att ingå i en omsorgskedja så är det i slutet av vårdkedjan. Boendet är ofta integrerat 
med andra grannar i mer eller mindre normala lägenheter och med få regler. Personaltillgängligheten är hög men de har låg grad av utbildning jämfört med andra vård- och behandlingsinsatser. Benämningen på insatsen är i hög utsträckning ett vedertaget begrepp som oftast betecknar samma sak i olika kommuner.

Sociala övergångskontrakt är den näst vanligaste insatsen och finns i drygt hälften av kommunerna (58 \%). Den utmärks av mycket hög grad av normalitet och samtidigt mycket låg grad av omsorg. Det är en varaktig insats, i en ordinär lägenhet, integrerad med andra grannar i samma trappuppgång. Den innehåller vidare mycket låg personaltillgång i form av tillsyn och med psykosocial kompetens. Den är tänkt för den som har små omsorgsbehov, antingen för att problemet är mer av ekonomisk art eller för att personen är i slutet på en rehabiliteringskedja.

Båda formerna av boendestöd - genom socialpsykiatri respektive övrig IFO - ligger mycket högt på normalitetsindex och har relativt hög omsorgsnivå, beroende på att det främst är en personell insats för att stödja de som har boende i normala boendebestånd. Skillnaden mellan de två slagen av boendestöd är att personal i boendestöd inom IFO har psykosocial kompetens medan personal i boendestöd inom socialpsykiatrin har medicinsk eller psykiatrisk inriktning.

Boendestöd inom IFO utan socialpsykiatrisk verksamhet förekommer i var femte kommun (19\%) och den sammanblandas begreppsmässigt främst med sociala övergångskontrakt och boendestöd med socialpsykiatrisk inriktning.
Boendestöd inom socialpsykiatrisk verksamhet är en entydig verksamhet som förekommer i så gott som alla kommuner och är den vanligaste av alla boendeinsatser (81 $\%)$.

Utifrån studiens två centrala dimensioner, normalitet och omsorg, kan insatserna indelas i fem skilda grupper:

1. Boendeinsats med hög normalitet och låg omsorg: Här återfinns endast sociala övergångskontrakt, som är mest likt vanligt boende och har karaktären av inkluderande insats.

2. Boendeinsatser med hög normalitet och hög omsorg: Här finns de båda formerna av boendestöd, dvs. vare sig de hör till socialpsykiatrisk eller övrig inom IFO -verksamhet. De är inriktade på omsorg för att möjliggöra kvarboende i egna lägenheter.

3. Boendeinsatser med låg normalitet och hög omsorg: Här finns vårdboende, halvvägshus, kategoriboende samt inackorderingshem. Detta är en grupp insatser som är mer institutionslika $i$ olika skeden av vård och omsorg.

4-5. Boendeinsatser med låg normalitet och låg omsorg: Dessa kan i sin tur delas in i två skilda grupper. Dels (4) akutboendeinsatser som ej ingår $i$ vårdkedja och omfattar härbärge, hotell och camping samt jourlägenhet och lågtröskelboende. Dels (5) boendeinsatser i slutet av vårdkedja och rymmer träningslägenhet och utslussningsboende. Dessa har ej karaktären av institution men liknar inte heller vanliga lägenheter.

Boendeinsatser som studien analyserat

Mats Blid: Boende och stöd - En nationell inventering av kommunernas... 
riktas till individer med olika grad av utanförskap och således med olika behov för att uppnå ökad grad av social förankring i boendesituationen och i samhället. Olika boendeinsatsers förekomst är berättigade om de befrämjar ökade möjligheter till livskvalitet, oberoende och delaktighet för klienten. Uppenbarligen ger "onormala" insatser sämre förutsättningar för individen att uppleva dessa värden än "normala» insatser gör. Detta kan möjligen motiveras i akuta skeden - innan mer normal lösning kan ordnas - eller i skeden då mer specifika vårdinsatser organiseras som på sikt skall hjälpa individen att kunna tillgodogöra sig mer "normala» bostadslösningar. Problemet är dels när akuta lösningar tenderar att per- manentas, dels när vårdens innehåll inte ger de fördelar som avses eller inte leder vidare till mer normala lösningar. Resultaten visar att de till omfattningen mest frekventa insatserna försöker kombinera vård med normalitet genom boendestöd i reguljärt boende. Behovet av insatser utanför detta - i den s.k. sekundära bostadsmarknaden - uppstår först sedan bostaden förlorats. Återförande av individen till normalt boende måste dock betonas som överordnat mål. Grupperingen i fem mer överordnade boendeinsatsgrupper, främst utifrån olika grad av normalitet och omsorg, bör underlätta fortsatta studier om socialpolitiska boendeprogram och koordination mellan interventioner och individuella behov.

\section{Referenser}

Blid, Mats \& Gerdner, Arne (2006) „Socially-excluding housing support to homeless substance misusers: two Swedish case studies of special category housing." International Journal of Social Welfare, nr 15, s. 162-171.

Bebout, Richard R (1999) "Housing Solutions: The Community Connections Housing Program: Preventing Homelessness by Integrating Housing and Supports." Alcoholism Treatment Quarterlynr 17, s. 93-112.

Bochel Catherine, Blochel Hugh \& Page Dilys (1999) »Housing: the foundation of community care?" Health and Social Care in the Community 7(6), s. 492-501.

Busch-Geertsema, Volker (2001) „När hemlösa själva får bestämma - bostäder åt hemlösa $\mathrm{i}$ Tyskland." I SOU 2001:95 Att motverka hemlöshet. En sammanhållen strategi för samhället. Bilagedel med expert- och forskningsrapporter till slutbetänkandet av Kommittén för hemlösa.

Börjeson, Martin (2005) Vi vet inte vilka metoder vi ska använda - om relationen mellan kunskap, praktik och politik när det gäller arbetet med hemlöshetsfrågor. Stockholm: Stockholms universitet, Socialhögskolan.

Cullhane Dennis P, Metraux Stephen \& Hadley Trevor R (2002) „Public Service Reductions Associated with Placement of Homeless Persons with Severe Mental Illness in Supportive Housing." Housing Policy Debate 13(1), s. 107163.

Daly, Mary (1992) Abandoned: profile of Europe's homeless people. Second report of the European observatory on homelessness. Berchem: Fédération Européenne d'Associations Nationales Travaillant avec les Sans-Abri, FEANTSA.

Edgar Bill, Doherty Joe \& Mina-Coull Amy (2000) 
Support and Housing in the Europe. Tackling social exclusion in the European Union. Bristol: The Policy Press.

Ericsson, Kent (2002) From institutional life to community participation. Ideas and realities concerning support to persons with intellectual disability. Uppsala: Pedagogiska institutionen, Uppsala universitet.

Fitzpatrick Suzanne \& Kemp Peter, Klinker Susanne (2000) Single homelessness. An overview of research in Britain. Bristol: Policy Press.

Gerdner, Arne \& Blid, Mats (2003) Hemlösa i fem kommuner - en aktstudie av 210 hemlösa och närmare 2250 flyttningsrörelser. Presentation vid Konferensen för Nordiska nätverket för forskning om hemlöshet, Köpenhamn, mars 2003.

Gullberg, Anders \& Börjeson, Martin (2000) Att undersöka grupper i svaga positioner påbostadsmarknaden. EpC-rapport 2000:4. Stockholm: Epidemiologiskt Centrum, Socialstyrelsen.

Hartwell, Stephanie (2003) „Deviance over the Life Course: The Case of Homeless Substance Abusers." Substance use \& misuse, 38(3-6), s. $475-502$.

Järvinen, Margareta (2001) "Institutionaliserad uppgivenhet - om utvecklingen av det danska behandlingssystemet." Nordisk alkohol \& narkotikatidskrift 18(2) s. 125-137.

Meert Henk, Edgar Bill \& Doherty Joe (2004) Towards an operational definition of homelessness and housing exclusion. Paper presented at the ENHR Conference, Cambridge.

Regeringsbeslut S 2003:9 Utredningen nationell psykiatrisamordning. Socialdepartmentet.

Ridgway Priscilla \& Zipple Anthony M (1990) »The paradigm shift in residential services: From the linear continuum to supported housing approaches." Psychosocial Rehabilitation Journal, 13(4), s. 11-31.

SFS 2000:1383 Lag om kommuners bostadsförsörjningsansvar.

Sahlin, Ingrid (1993) Socialtjänsten och bostaden. Redovisning av en enkätundersökning om soci- altjänstens metoder och resurser att lösa klienternas bostadsproblem. Research Report. Lund: Sociologiska institutionen, Lunds universitet.

Sahlin, Ingrid (1996) På gränsen till bostad. Avvisning, utvisning, specialkontrakt. Lund: Arkiv förlag.

Sahlin, Ingrid (1999) Supported Accommodation. Swedish National Report. European Observatory on Homelessness. Bryssel: Fédération Européenne d'Associations Nationales Travaillant avec les Sans-Abri, FEANTSA

Sahlin, Ingrid (2005) "The Staircase of Transition: Survival through failure." Innovation, 18(2), s. 115-135.

Socialstyrelsen (2000) Hemlösa i Sverige 1999. Vilka är de och vilken hjälp fär de? Socialstyrelsen följer upp och utvärderar 2000:1. Stockholm: Socialstyrelsen.

Socialstyrelsen (2006) Hemlöshet $i$ Sverige 2005. Omfattning och karaktär. Stockholm: Socialstyrelsen.

SOU 2000:14 Adressat okänd. Om hemlöshetens bakgrund, orsaker och dynamik. Delbetänkande av kommittén för hemlösa.

SOU 2001:95 Att motverka hemlöshet. En samman hållen strategi för samhället. Slutbetänkande av Kommittén för hemlösa.

SOU 2005:88 Vräkning och hemlöshet - drabbar ocksåbarn. Slutbetänkande av Utredningen om vräkning och hemlöshet bland barnfamiljer.

Streiner, David L \& Normann, Geoffrey R (1989) Health measurement scales: a practical guide to their development and use. Oxford: Oxford University Press.

Svenska Kommunförbundet (2003) (www.svekom. se 2006-09-08).

Tabachnick, Barbara \& Fidell, Linda (1996) Using Multivariate Statistics. Boston: Allyn and Bacon.

Tsemberis Sam, Eisenberg Ronda (2000)»Pathways to Housing: Supported Housing for StreetDwelling Homeless Individuals with Psychiatric Disabilities." Psychiatric Services 51(4), s. 487-493.

Mats Blid: Boende och stöd - En nationell inventering av kommunernas... 


\section{Summary}

\section{Housing and support - a national inventory of municipal housing support for vulnerable groups}

The article introduces a national inventory of housing intervention programmes for individuals who for various reasons do not have stable accommodation. Housing intervention implies both personal support in one's own apartment and an offer of different forms of accommodation. The interventions are studied on the basis of different characteristics.

The empirical material comes from a survey of 147 randomly chosen municipalities (about half of Sweden) reporting 386 housing interventions with a caseload of 11,187 individuals. They could be categorized in the following groups: night shelter, camping and hotel, low-threshold housing, treatment institution, half-way house, after-care housing, re-entry/training apartment, boarding home, category house (group housing for alcoholics), sub-leased normal apartment and two kinds of housing support (organized within a social-psychiatric context or not).

The different housing interventions were statistically analysed to distinguish similarities and differences, and two indexes level of normality and level of care were created. Based on these, all housing interventions were categorized in five groups: social sublet contract in normal housing, support and care in regular housing, residence and care institutions, low-threshold housing outside the continuum of care and re-entry housing at the end of the continuum of care. The findings should facilitate further studies on housing intervention policies and promote coordination of interventions to meet individual needs. 